\title{
Religion, Spirituality and Alcoholism
}

\author{
Ayman M Hamdan Mansour* \\ Mental Health Nursing, School of Nursing, The University of Jordan, Jordan
}

Submission: December 16, 2017; Published: March 22, 2018

*Corresponding author: Mental Health Nursing, School of Nursing, the University of Jordan. Queen Rania Street, Amman, Jordan, Tel: 9626 5355000; Email: aymanjabay@gmail.com

\begin{abstract}
Despite of the belief that religion and spirituality considered the most important cultural factors that give meaning to human behaviors and values, religion and spirituality have been equally ignored in the empirical alcohol studies. The purpose of this paper is to discuss alcohol use and abuse among and its relationship to religion and spirituality. Integrative review has been utilized to address the issue. There is a presentation of findings from research examining religion and spirituality and their relationship to alcoholism. Treatment requires awareness of underlying causes in order to establish effective treatment approaches. Determining these underlying causes requires adequate knowledge of underlying personal beliefs and values that adheres to religions and spirituality. Health professionals across disciplines have an important role in implementing multidisciplinary interventions. Results, controversies and concerns raised by the reported results are addressed.
\end{abstract}

Keywords: Alcoholism; Belief System; Religion; Spirituality

\section{Introduction}

In the last few decades, there has been a growing public interest in alcoholism and methods of treatment of alcoholism. Alcohol is a widely used substance throughout all ages and ethnic groups. It affects families and societies financially and developmentally. Alcohol is considered as the most recurrent brain depressant throughout the different cultures and the cause of remarkable number of diseases and deaths [1]. Despite of the belief that religion and spirituality considered the most important cultural factors that give meaning to human behaviors and values, religion and spirituality have been equally ignored in the empirical alcohol studies [2]. This paper tries to explore issues related to the alcoholism from spiritual and religious perspectives. The discussion will include a review of studies and treatment approaches that support the efficiency of using the spiritual and religious dimension in alcohol recovery.

\section{Religion and Spirituality}

The word religion is taken from the Latin word religare which means "to bind together" [3]. Religion reflects a set of beliefs and practices that are agreed upon specific groups of people. These beliefs may be related to nature and cause of things and the purpose of universe. The degree to which individual devote or the quality of being religious refers to religiosity or religious involvement. Spirituality is taken from the word spiritualitas which means "breath". Spirituality can be defined as "a broad concept that encompasses values, meaning and purposes; one turn inward to the human traits of honesty, love wisdom, caring, imagination, compassion, existence of quality of a higher authority, guiding spirit or transcendence that is mystical; a lowing, dynamic balance that allows and creates healing of body-mind spirit; and may or may not involve organized religion" [3] p24). Three characteristics of spirituality as posited by Margaret Burkhardt [4] are: unfolding mystery, harmonious interconnectedness, and inner strength. Some researchers use the term spiritual well being to refer to spirituality. But these two terms are different. Spiritual well being refers to "the affirmation of life in relationship with God, self, community and environment that nurtures and celebrates wholeness.

Spiritual well-being is first emerged by David 0. Moberg in 1971 where he defined it as "wellness or health of the totality of the inner resources of people, the ultimate concerns around which all other values are focused, the central philosophy of life that guide the conduct, the meaning-giving center of human life which influences all individual and social behavior" [5], p2). Carson maintained that spiritual well being is not a state but rather an indicative of the presence of spiritual health in the person. The features of spirituality includes connectedness with others and divine, transcendence (the human is more than simple materials), and values as love and justice. The issues of measuring spirituality become one of the main concerns for the workers in the sociocultural and psychosocial disciplines. For those who believe that spirituality cannot be measured, they rely on defining spirituality as being composed of self or body, mind and emotions, and the spiritual power in the universe. Therefore, drug and alcohol abuse is considered as a symptom of wounded spirituality. 


\section{Religion and Spirituality: A Linking Process to Health and Wellbeing}

The association between high spirituality and religiosity with physical and psychosocial well-being has been strongly recommended in the literature [6]. Religiousness has been found to be negatively associated with rates of depression, suicide, and cognitive dysfunction. Spirituality found to associate with individual's experience of health and pain. Further, religious practices are inversely related to severity of symptoms and hospital use, and enhance life satisfaction among psychiatric inpatients. This indicated why there are many people turned to the alternative medicine because it corresponds with their beliefs, values and philosophical orientation and because of dissatisfaction with the conventional medicine [7]. However, religion has been reported with some negative consequences on the individual's health behaviors and practices such as, obesity, obsessive behaviors, and adherence to medical regimens and procedures. While some of these beliefs may not be accepted by the health care providers and other allied professionals, ethicists suggest that these beliefs must be respected [7].

Most of clinical studies and population surveys noted that religiosity and alcohol use are inversely related. Religiously is more related to use of alcohol than abstinence. Even in maintaining abstinence, the religious individuals show more significant results in term of longer abstinence period [8]. In fact, addicted people reported lack of religious affiliation and involvement, and spiritual-focused intervention, and further, those who rely less on their belief system and less likely to use health-related behavior [9]. Although Arab societies seem to social integrate religion and spirituality in their social systems, religion and spirituality have not been seriously integrated in their health behaviors or treatment process. It has been reported also that nurses do not utilized individual value and belief system in to their usual care, and thus, patients have not considered that as part of their evaluation for quality of nursing care [10]. This also has been observed while investigating coping mechanism of abuse women in which they have mainly relied psychological factors rather than using their belief system or religion as part of social integration component [11]. In conclusion, spirituality and religion although been considered one significant component for wellness and health, have not been utilized to promote health of individuals. This sustains the notion that religion and spirituality are directly used and identified by individuals; and rather, utilized and integrated with other social and psychological components that are much clear and less threatening and challenging.

\section{Implication and Research Issues}

The reviewed studies on alcoholism and its relationship with religion and spirituality acknowledge the role of religious/ spiritual affiliation as a protective factor against alcohol and drug abuse. Although some studies revealed positive relationship between the religious/spiritual involvement and recovery from alcohol; however, the limited empirical evidence limits the ability for establishing predictive relationship. The evidence of religious and spiritual practices in protecting against addiction logically implies that these practices can be used effectively in the process of recovery. That requires more understanding of the alcohol or addict's spirituality and religious affiliation. Further, the health care providers and allied care providers are urged to include the outcomes of spiritual assessment planning and interventional processes. Moreover, the researchers need to investigate more the relationship between alcohol recovery and spiritual/religious involvement and include the spiritual variables in the treatment studies.

\section{References}

1. American Psychological Association (2013) Diagnostic and statistical manual of mental disorders ( $5^{\text {th }}$ edn), Washington, DC, USA.

2. Gove PB (1986) Webster third new international dictionary: of the English language unabridged. Springfield, Massachusetts Merriam Company, USA.

3. Dossey BM (1989) The transpersonal self and states of consciousness, in Holistic health promotion: A guide for practice. LG Kolkmeier, CE Guzzetta (Eds.) Aspen,Rockville, Maryland, p. 23-35.

4. Burkhardt MA (1989) Spirituality: An analysis of the concept. Holistic Nursing Practice 3(3): 69-77.

5. Moberg DO (1979) The development of social indicators of spiritual well-being and quality of life, in Spiritual well-being: sociological perspective. University press of America, Washington, DC, USA.

6. Baetz M, Larson DB, Marcoux G, Bowen R, Griffin R (2002) Canadian psychiatric inpatient religious commitment: an association with mental health. Canadian Journal of Psychiatry, Revue Canadienne de Psychiatrie 47(2): 159-166.

7. Van Ness PH, Larson DB (2002) Religion, senescence, and mental health: the end of life is not the end of hope. American Journal of Geriatric Psychiatry 10(4): 386-397.

8. Hamdan Mansour A, Dardas L, AbuAsba M, Nawafleh HA (2012) Predictors of anger among university students in Jordan. Children Youth Ser Rev 34(2): 474-479.

9. Shaheen AM, Nassar OS, Amre HM, Hamdan Mansour AM (2015) Factors Affecting Health-Promoting Behaviors of University Students in Jordan. Health 7(1): 1-8.

10. Attallah MA, Hamdan Mansour AM, Al Sayyed MM, Aboshaiqah A (2013) Patient Satisfaction with the quality of nursing care provided: the Saudi experience. Inter J Nur Pract 19(6): 584-590.

11. Hamdan Mansour AM, Arabiat D, Sato T, Imoto A, Obiad B (2011) An Investigation into Marital Abuse and Psychological Wellbeing among Women in the Southern Region of Jordan. J Transcultl Nur 22(3): 265273. 

(C) Commons Attribution 4.0 License BY DOI: 10.19080/JOJNHC.2018.07.555702
Your next submission with Juniper Publishers will reach you the below assets

- Quality Editorial service

- Swift Peer Review

- Reprints availability

- E-prints Service

- Manuscript Podcast for convenient understanding

- Global attainment for your research

- Manuscript accessibility in different formats

( Pdf, E-pub, Full Text, Audio)

- Unceasing customer service

Track the below URL for one-step submission https://juniperpublishers.com/online-submission.php 